\title{
Relationship between Refractive Visual Errors and Cervical Spine Angles and Range of Motion
}

\author{
ARWA A.M. IDRES, M.Sc.****; SOHEIR SHEHATA, Ph.D.*; YASSR RAMZY, Ph.D.* and \\ MANAR HUSSEIN, M.D.** \\ The Departments of Basic Science* and Ophthalmology**, Faculty of Physical Therapy, Cairo University*, Faculty of Medicine, \\ Cairo University** and Oseem Hospital ***
}

\begin{abstract}
Background: Myopia is one of the common Refractive Visual Errors (RVE) that produces musckeloskeltal complaines, such as stiffness, fatigue and muscular pain in the neck which in turn may affect cervical curvature and range of motion.

Aim of Study: To investigate the relationship between refractive visual errors subjects and cervical curvature and cervical range of motion.

Patients: Fifty participants 15-30 years old from Kasr Al-Aini Hospital in October 2016. They assigned in two equal groups refractive myopic and normal sighted).

Methods: Cervical Range of Motion (CROM) was assessed by using O.B gonyometer, cervical angles $\left(\mathrm{OC}-\mathrm{C}_{2}, \mathrm{C} 1-\mathrm{C} 2\right.$, $\mathrm{C} 2-\mathrm{C} 7$ ) were measures by using corel draw program in X-ray.

Results: Comparison between groups revealed no significant different in $\mathrm{OC}-\mathrm{C}_{1}$ and a significant different in $\mathrm{C} 1-\mathrm{C} 2$ and $\mathrm{C} 2-\mathrm{C} 7$, additionally there was a significant difference in flexion, extension, Rt. and Lt. rotation ( $p=0.007,0.01,0.0001$, 0.001 ) between groups respectively, there was no significant correlation between right and left eye and cervical angles and range of ROM.
\end{abstract}

Conclusion: Myopia causes changes in cervical curve and ROM but the degree of Myopia is not correlated to this changes of cervical curve and ROM.

Key Words: Refractive visual errors - Cervical range of motion - Myrine O.B goniometer-Corel - Draw program in $X$-ray

\section{Introduction}

VISION is one of the most important senses, functionally affecting other senses and motor control, thereby exercising vital effects on many bodily systems which, in turn, crucially affect everyday functioning and comfort, the influence of the visual system on postural control has been documented in several studies [1]. Visual problems can be related

Correspondence to: Dr. Arwa A.M. Idres,

The Department of Basic Science, Faculty of Physical Therapy, Cairo University and Oseem Hospital*** to systemic, body structural, postural and cognitive dysfunctions which with time lead to disorganization and to disease. Conversely dysfunctions in the body posture, dynamics and structure and changes to these can be directly related to ocular and visual problems [2]. Previous studies explore the extent to which RVE is associated with neck area muscular dysfunction and/or discomfort. The relative impact of the different aspects of visual function on musculoskeletal functioning of cervical spine will be of particular interest in this context [3].

Patients with visual dysfunction must place a greater demand on somatosensory and vestibular information to maintain postural stability, establish and connect movement patterns and adjust to positions in space to compensate for low-functioning visual systems [4].

Neurophysiological mechanisms of gaze control offer a theory of why and how dysfunctional interactions between eye function and head-neckshoulder activity can be initiated. Among these, common drive mechanisms offer a particularly interesting explanatory scheme. A variation of oculomotor load was obtained By combining an alteration of visual distance and the application of minus lenses [5].

In real-life tasks, the visiomotor consequence (feedback) about the outcome of a goal-directed arm and hand movement becomes less accurate in low vision. Acorns-trained visiomotor control strategy, aggravated by muscle stiffness and cocontraction of muscles not directly involved in producing the desired reach-to-grasp movement, is likely to result as compensation [6]. The result may be prolonged static load leading to the devel- 
opment of fatigue, stiffness, muscular pain, as well as to disturbed proprioception, balance problems and dizziness [7].

\section{Purpose of the study:}

To investigate the relationship between cervical spine angles (occipitocervical angle "Oc- $\mathrm{C}_{2}$ ", atlantoaxial angle" $\mathrm{C}_{1}-\mathrm{C}_{2}$ " and subaxial angle " $\mathrm{C}_{2}$ $\left.\mathrm{C}_{7} "\right)$ and cervical active range of motion (CROM) and refractive errors (Myopia).

Design of the study:

The design of the study is Ex post Facto design.

\section{Patients and Methods}

Participant:Fifty participantof both genderparticipated there were assigned in two equal groups: Each group consists of twenty five person. Group A: Group A included twenty five "25" myopic. Participant. Group B: Group B included twenty five "25" normal sighted individual.

They were selected from Kasr El-Einy, Faculty of Medicine, Cairo University. The study was conducted from May 2015 to October 2017. From Ophthalmology Department, Cervical Range of Motion (CROM) was assessed by using myrine O.B Goniometer, and measure cervical angles by using corel draw program on X-ray. Their inclusion criteria were as follow: Age from 15-30 years, body mass index (18.5-24.9).

\section{Assessment:}

\section{For measurement:}

1-X-rays: Imaging of cervical curvature: Omni 94 Philips X-rays device that emits highly penetrating, ionizing radiation, therefore $\mathrm{X}$-rays machines are used to take pictures of dense tissues such as bones.

\section{Cervical angles measurement using X-ray Imaging:}

In all cases, standard standing lateral cervical radiographs were obtained with subject's right shoulder against the cabinet with a standard tube distance of $182.9 \mathrm{~cm}$ (72 inches). Before the lateral $\mathrm{X}$-ray, all subjects were asked to assume a neutral lateral cervical posture, they were looking straight ahead, the eyes were opened and the subject was asked not to move [8]

Angles were measured using radiographs: (A) Occipital to 2 nd cervical $\left(\mathrm{Oc}-\mathrm{C}_{2}\right)$ : Angle between McGregor line and the line tangential to the inferior aspect of the axis was defined as the Oc- $\mathrm{C}_{2}$ angle. (B) 1 st and 2 nd cervical $\left(\mathrm{C}_{1}-\mathrm{C}_{2}\right)$ : Angle between inferior aspect of atlas and axis. (C) Sagittal align- ment of 2 nd to $7^{\text {th }}$ cervical vertebrae $\left(\mathrm{C}_{2}-\mathrm{C}_{7}\right)$ : Angle between the posterior aspect of vertebral bodies of $\mathrm{C} 2$ and $\mathrm{C} 7$ [9]

2- ACROM: Evaluation of cervical spine active Range of Motion (ROM) using Myringravity reference goniometer (OB goniometer): $\mathrm{OB}$ goniometer consists of a fluid filled rotatable container mounted on a plate. Myrine (OB) Rehab Co AN LIC-Company s-17183 Solna, Sweden. The container has: (A)Compass needle that react to the earth's magnetic field. (B) An inclination needle that is influenced by the force of gravity. (C) Scale on the container floor marked in 2 increments $(1$ minor unit $=2: 1$ major unit $=10$ ) [10]

The researcher found the OB goniometer to have fair to high intrataster reliability for measurements of active cervical spine flexion and extension and lateral flexion using the inclinometer and cervical spine rotation using the compass goniometer [11].

OB Goniometer "Myrin" makes it possible to measure accurately the movement of most of the body's joints. The instrument consists of a small fluid-filled box fixed to a plate upon which is affected by the earth's magnetic field, and an inclination needle which is affected by gravity.

Movement in the horizontal plane round a vertical axis is read form the compass needle.

The box is fixed to the appropriate part of the body with the help of a Velcro fastening strap. N.B. that the compass needle can be affected by the influence of iron in the examination couch or nearby objects.

Therefore the axis of the instrument should be placed as near as possible to the axis of the joint whose movement is to be measured. This is made possible by the extension plate [12].

\section{Statistical analysis:}

- All Statistical Package for Social Studies (SPSS) Version 19 for windows.

- Descriptive analysis and $t$-test were conducted for comparison of the mean age between both groups.

- One way multivariate analysis of variance (MANOVA) was conducted for comparison of cervical angles and R.O.M of both groups.

- Person product moment correlation coefficient was conducted to investigate the correlation between refractive visual errors (Myopia) and cervical spine angles and R.O.M. 
- The level of significance for all statistical tests was set at $p<0.05$.

\section{Results}

\section{Subject characteristics.}

\section{Group A: Refractive visual errors group:}

Twenty-five subjects (20 females and 5 males) with myopia were included in this group. Their mean \pm SD age was $20.64 \pm 3.83$ years as shown in (Table 1).

\section{Group B: Normal group:}

Twenty-five subjects ( 18 females and 7 males) normal sighted were included in this group. Their mean \pm SD age was $20.84 \pm 2.3$ years as shown in (Table 1).

Comparing the general characteristics of the subjects of both groups revealed no significance difference between both groups in the mean age $(p=0.52)$.

Table (1): Descriptive statistics and $t$-test for comparison of the mean age of both groups (A and B).

\begin{tabular}{|c|c|c|c|c|c|}
\hline & $\begin{array}{l}\text { Group A Group B } \\
X \pm S D \geq \pm S D\end{array}$ & MD & $\begin{array}{c}t- \\
\text { value }\end{array}$ & $\begin{array}{c}p- \\
\text { value }\end{array}$ & Significance \\
\hline $\begin{array}{l}\text { Age } \\
\text { (years) }\end{array}$ & $20.64 \pm 3.83 \quad 21.32 \pm 3.6$ & $8-0.68$ & -0.63 & 0.52 & NS \\
\hline 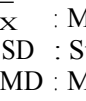 & $\begin{array}{l}\text { lean. } \\
\text { tandard Deviation. } \\
\text { Iean Difference. }\end{array}$ & $\begin{array}{l}t \text {-valu } \\
p \text {-val } \\
\mathrm{NS}\end{array}$ & $\begin{array}{l}\text { ue }: \text { Un } \\
\text { : Pro } \\
\quad: \text { No }\end{array}$ & $\begin{array}{l}\text { paired } \\
\text { obability } \\
\text { o Signi }\end{array}$ & $\begin{array}{l}t \text {-value. } \\
\text { y value. } \\
\text { ficant. }\end{array}$ \\
\hline
\end{tabular}

Table (2): Descriptive statistics for the refraction visual errors of group A.

\begin{tabular}{lclll}
\hline $\begin{array}{l}\text { Refraction visual } \\
\text { errors (Diopter) }\end{array}$ & $\mathrm{X} \pm \mathrm{SD}$ & Minimum & Maximun & Range \\
\hline $\begin{array}{l}\text { Right eye } \\
\text { Left eye }\end{array}$ & $-3.12 \pm 1.36$ & -6.75 & -0.5 & 6.25 \\
\hline
\end{tabular}

X: Mean. $\quad$ SD: Standard Deviation.

Post-comparison of cervical angles between group $A$ and $B$ :

The mean $\pm \mathrm{SD}$ Oc- $\mathrm{C}_{2}$ angle of group A was $15.29 \pm 0.56$ degrees and that for group B was 15.16 \pm 0.6 degrees. The mean difference between both groups was 0.13 . There was no significant difference in Oc- $\mathrm{C}_{2}$ angle between group $\mathrm{A}$ and $\mathrm{B}(p=$ 0.45) (Table 4).

The mean $\pm \mathrm{SD} \mathrm{C}_{1}-\mathrm{C}_{2}$ angle of group A was $28.08 \pm 1.22$ degrees and that for group B was 26.2 \pm 0.71 degrees. The mean difference between both groups was 1.88. There was a significant increase in $\mathrm{C}_{1}-\mathrm{C}_{2}$ angle in group A compared with that of group $\mathrm{B}(p=0.0001)$ (Table 4$)$.
The mean $\pm \mathrm{SD}$ C2-C 7 angle of group A was $9.74 \pm 0.53$ degrees and that for group B was 16.49 \pm 0.27 degrees. The mean difference between both groups was 6.75 . There was a significant decrease in $\mathrm{C}_{2}-\mathrm{C} 7$ angle in group $\mathrm{A}$ compared with that of group $\mathrm{B}(p=0.0001)$ (Table 3$)$.

Table (3): Comparison of the cervical angles between the both groups (A and B).

\begin{tabular}{|c|c|c|c|c|c|c|}
\hline $\begin{array}{l}\text { Cervical } \\
\text { angles } \\
\text { (degrees) }\end{array}$ & $\begin{array}{l}\text { Myopa } \\
\bar{X} \pm \text { SD }\end{array}$ & $\begin{array}{l}\text { Normal } \\
\text { sighted } \\
\mathrm{X} \pm \mathrm{SD}\end{array}$ & MD & $\begin{array}{c}\text { F- } \\
\text { value }\end{array}$ & $\begin{array}{c}p- \\
\text { value }\end{array}$ & Sig. \\
\hline $\mathrm{Oc}-\mathrm{C} 2$ & $15.29 \pm 0.56$ & $15.16 \pm 0.6$ & 0.13 & 0.57 & 0.45 & NS \\
\hline $\mathrm{C} 1{ }^{-} \mathrm{C} 2$ & $28.08 \pm 1.22$ & $26.2 \pm 0.71$ & 1.88 & 44.15 & 0.0001 & S \\
\hline $\mathrm{C} 2 \mathrm{C} 7$ & $9.74 \pm 0.53$ & $16.49 \pm 0.27$ & -6.75 & 3203.47 & 0.0001 & $\mathrm{~S}$ \\
\hline 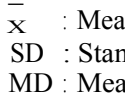 & $\begin{array}{l}\text { dard Deviatic } \\
\text { n Difference. }\end{array}$ & S & & $\begin{array}{l}\text { Probabilit } \\
\text { Non Signi } \\
\text { Significan }\end{array}$ & $\begin{array}{l}\text { value. } \\
\text { ficant. }\end{array}$ & \\
\hline
\end{tabular}

Comparison of cervical ROM between group $A$ and $B$.

The mean \pm SD flexion ROM of group A was $53 \pm 4.56$ degrees and that for group B was $56.4 \pm$ 3.95 degrees. The mean difference between both groups was -3.4 degrees. There was a significant decrease in flexion ROM in group A compared with that of group $\mathrm{B}(p=0.007)$ (Table 4$)$.

The mean $\pm \mathrm{SD}$ extension ROM of group A was $60.8 \pm 5.33$ degrees and that for group $\mathrm{B}$ was $65.2 \pm 6.53$ degrees. The mean difference between both groups was -4.4 degrees. There was a significant decrease in extension ROM in group A compared with that of group $\mathrm{B}(p=0.01)$ (Table 5).

The mean \pm SD right lateral flexion ROM of group A was $33 \pm 4.08$ degrees and that for group $B$ was $35.2 \pm 4.67$ degrees. The mean difference between both groups was -2.2 degrees. There was no significant difference in right lateral flexion ROM between group A and B ( $p=0.08)$ (Table 4).

The mean \pm SD left lateral flexion ROM of group A was 33.4 \pm 4.01 degrees and that for group $\mathrm{B}$ was $35 \pm 4.33$ degrees. The mean difference between both groups was -1.6 degrees. There was no significant difference in left lateral flexion ROM between group $\mathrm{A}$ and $\mathrm{B}(p=0.18)$ (Table 4).

The mean \pm SD right rotation ROM of group A was $72.6 \pm 4.59$ degrees and that for group B was $78 \pm 3.81$ degrees. The mean difference between both groups was -5.4 degrees. There was a significant decrease in right rotation ROM in group A compared with that of group B ( $p=0.0001)$ (Table 5). 
The mean \pm SD left rotation ROM of group A was $71.4 \pm 5.5$ degrees and that for group B was $76.2 \pm 3.61$ degrees. The mean difference between both groups was 4.8 degrees. There was a significant decrease in left rotation ROM in group A compared with that of group B $(p=0.001)$ (Table 4).

Table (4): Comparison of the cervical ROM between the both groups (A and B).

\begin{tabular}{lllllll}
\hline $\begin{array}{l}\text { Cervical } \\
\text { ROM } \\
\text { (degrees) }\end{array}$ & $\begin{array}{l}\text { Group A } \\
\text { X } \pm \text { SD }\end{array}$ & $\begin{array}{c}\text { Group B } \\
\text { X SD }\end{array}$ & MD & $\begin{array}{c}\text { F- } \\
\text { value }\end{array}$ & $\begin{array}{c}p \text { - } \\
\text { value }\end{array}$ & Sig. \\
\hline - Flexion & $53 \pm 4.56$ & $56.4 \pm 3.95$ & -3.4 & 7.91 & $0.007^{*}$ & $\mathrm{~S}$ \\
- Extension & $60.8 \pm 5.33$ & $65.2 \pm 6.53$ & -4.4 & 6.8 & $0.01 *$ & $\mathrm{~S}$ \\
$\begin{array}{l}\text { - Right lateral } \\
\text { flexion }\end{array}$ & $33 \pm 4.08$ & $35.2 \pm 4.67$ & -2.2 & 3.14 & 0.08 & $\mathrm{NS}$ \\
$\begin{array}{l}\text { - Let lateral } \\
\text { flexion }\end{array}$ & $33.4 \pm 4.01$ & $35 \pm 4.33$ & -1.6 & 1.83 & 0.18 & $\mathrm{NS}$ \\
$\begin{array}{l}\text { - Right rotation } \\
\text { - Left rotation }\end{array}$ & $72.6 \pm 4.59$ & $78 \pm 3.81$ & -5.4 & 20.43 & $0.0001^{*}$ & $\mathrm{~S}$ \\
\hline
\end{tabular}

\section{I- Relationship between refraction visual errors} and cervical angles:

The correlations between refraction visual errors of the right eye and cervical angles were weak positive non significant correlations with Oc- $\mathrm{C}_{2}$ angle $(r=0.02, p=0.91)$ and with $\mathrm{C}_{1}{ }^{-} \mathrm{C}_{2}$ $(r=0.25, p=0.22)$, while was weak negative non significant correlation with $\mathrm{C}_{2}-\mathrm{C} 7 \quad(r=0.21$, $p=0.31$ ) (Table 6).

The correlations between refraction visual errors of the left eye and cervical angles were weak positive non significant correlations with Oc- $\mathrm{C}_{2}$ angle $(r=0.22, p=0.28)$ and with $\mathrm{C}_{1}-\mathrm{C}_{2}(r=0.08, p$ $=0.68)$, while was weak negative non significant correlation with $\mathrm{C} 2-\mathrm{C} 7(r=-0.3, p=0.14)$ (Table 5).

Table (5): Correlation between right and left eye and cervical angles in group A.

\begin{tabular}{lcccc}
\hline $\begin{array}{l}\text { Refraction visual } \\
\text { errors (Diopter) }\end{array}$ & $\begin{array}{c}\text { Cervical angles } \\
\text { (degrees) }\end{array}$ & $r$-value & $p$-value & Sig. \\
\hline Right eye & Oc-C2 & 0.02 & 0.91 & NS \\
& C1-C2 & 0.25 & 0.22 & NS \\
& C2-C7 & -0.21 & 0.31 & NS \\
\hline \multirow{2}{*}{ Left eye } & & $r$-value & $p$-value & Sig \\
& & & & \\
& Oc-C2 & 0.22 & 0.28 & NS \\
& C1 ${ }^{-}$C2 & 0.08 & 0.68 & NS \\
& C2 ${ }^{-C} 7$ & -0.3 & 0.14 & NS \\
\hline
\end{tabular}

$r$-value : Pearson correlation coefficient.

$p$-value : Probability value.

NS : Non Significant.

\section{II- Relationship between refraction visual errors} of the right eye and cervical ROM:

The correlations between refraction visual errors of the right eye and cervical ROM were weak positive non significant correlations withflexion ROM ( $r=0.1, p=0.62$ ), weak negative non significant correlation with extension ROM ( $r=-0.09, p$ $=0.64)$, weak negative non significant correlation with right lateral flexion ROM ( $r=-0.05, p=0.81$ ), weak positive non significant correlation with left lateral flexion ROM $(r=0.1, p=0.61)$, weak negative non significant correlation with right rotation ROM $(r=-0.08, p=0.69)$, and weak negative non significant correlation with left rotation ROM ( $r=-0.11$, $p=0.59)$ (Table 6).

Table (6): Correlation between refraction visual errors of the right and left eye and cervical ROM.

\begin{tabular}{llccc}
\hline $\begin{array}{l}\text { Refraction visual } \\
\text { errors (Diopter) }\end{array}$ & $\begin{array}{c}\text { Cervical ROM } \\
\text { (degrees) }\end{array}$ & $r$-value & $p$-value & Sig. \\
\hline Right eye & Flexion & 0.1 & 0.62 & NS \\
& Extension & -0.09 & 0.64 & NS \\
& Right lateral flexion & -0.05 & 0.81 & NS \\
& Let lateral flexion & 0.1 & 0.61 & NS \\
& Right rotation & -0.08 & 0.69 & NS \\
& Left rotation & -0.11 & 0.59 & NS \\
\hline & & $r$-value & $p$-value & Sig. \\
\hline Left eye & Flexion & 0.05 & 0.79 & NS \\
& Extension & -0.11 & 0.59 & NS \\
& Right lateral flexion & 0.05 & 0.8 & NS \\
& Let lateral flexion & 0.03 & 0.86 & NS \\
& Right rotation & -0.16 & 0.41 & NS \\
& Left rotation & -0.006 & 0.79 & NS \\
\hline
\end{tabular}

$r$-value : Pearson correlation coefficient. $p$-value : Probability value.

NS : Non Significant.

\section{III- Relationship between refraction visual errors} of the left eye and cervical ROM:

The correlations between refraction visual errors of the left eye and cervical ROM were weak positive non significant correlations withflexion ROM $(r=0.05, p=0.79)$, weak negative non significant correlation with extension ROM ( $r=-0.11, p=0.59$ ), weak positive non significant correlation with right lateral flexion $\operatorname{ROM}(r=0.05, p=0.8)$, weak positive non significant correlation with left lateral flexion ROM ( $r=0.03, p=0.86)$, weak negative non significant correlation with right rotation ROM ( $r=-0.16$, $p=0.41$ ), and weak negative non significant correlation with left rotation ROM ( $r=-0.006, p=0.79$ ) (Table 7).

\section{Discussion}

The study was conducted to determine changes in cervical curvature and range of motion between myopic and normal sighted individuals. 
Fifty adult both gender ( 38 female 12 male) participated in thisstudy. Their age ranged from 15-30 years old, divided into two groups Myopia and the other is normal sighted group.

The need of the study arises from the importance to maintain normal cervical lordosis to protect basic biomechanical balance of cervical spine, through intricate interralation between physiological lordosis and intervertebral disc edge space height, the loss of cervical lordosis has been postulated to cause numerous conseqences in health include decrease vital lung capacity, cervical, interscapular pain, headache and tempromandibular disorder [13]

The mean value of $\mathrm{C2}_{\mathrm{C}} \mathrm{C}$ was greatly lower in myopia than in normal sighted participants $(p<0.0001)$ decrease in $\mathrm{C} 2-\mathrm{C} 7$ means flattening in cervical curve or loss of cervical lordosis and this occur due to assuming forward head position despite cervical lordosis increases progressively with age. This agrees with Harrison et al., who reprted that lossof cervical occure in flexion [14]. Also agrees with Hodgson who reported that the bad posture creates straightening and foreward leaning of neck [15]

Alteration in Oc-c ${ }_{2}$ and $\mathrm{c} 1-\mathrm{c}_{2}$ angles was examined by X-rays, and compare to normal sighted people, the result show no significant changes in Oc-c $c_{2}$ angle while showing significantly increase in $\mathrm{c} 1-\mathrm{c} 2_{2}$ angle with normal value. To achieve global balance in cervical spine, and to maintain horizontal gaze the upper cervical angle $\mathrm{c1}$-c2 increase when $c_{2}{ }^{-} c_{7}$ decreased. This result come inagreement with Radcliff reported that the normal OA angulation is partially dependent on the alignment of the lower spinal segment, particularly the cervical and thoracic spine [16]. Patients with sub axial kyphosis commonly develop hyperextension at the $\mathrm{OA}$ articulation to maintain horizontal gaze, also Wang S. found patients with anterior dislocation of atlas generally have kyphotic alignment in occipital cervical junction with hyperlordosis of the lower cervical spine [17]. The hyperlordosis was though to serve as compensation to achieve global balance. In contrast to the finding in those with anterior dislocation, the alignment of the subaxial cervical spine in patient with posterior dislocation of the atlas was shown to be straight or even kyphotic, thus reversing the physiological lordosis. This findings imply that the primary compensation to achieve balance.

To show alteration in cervical ROM, Myrin goniometer was used to measure the active flexion, extension, right side bending, left side bending, right rotation and left rotation. The result showed that AROM of cervical decreased in flexion, extension right and left rotation wich agrees with. Observations from ophthalmology clinics indicates that RVE patients, besides their visual deficits, also report musculoskeletal complaints, such as stiffness, fatigue and muscular pain in the neck/ scapular, RVE patients and other people with low vision may be at increased risk of developing musculoskeletal problems in the neck/scapular area, regardless of their age, and [18]. Musculoskeletal problems may also arise due to disturbed eyehand coordination. Skilled reach-to-grasp movements will likely not be appropriately performed [19]. Variation of oculomotor load was obtained by combining an alteration of visual distance and the application of minus lenses, increases in Electromyography (EMG) amplitudes were observed in the rightfrontalis, masseter, deltoid, middle trapezius, levator and upper trapezius and upper neck muscles, includingthe splenius. A correlation between visual discomfort and pain in the neck and shoulder has been reported this observation was attributed to the extraocularmuscles being in a state of static stress to prevent fatiguingmuscles from producing disturbing double visionand to the reflex optic paths being at the origin of, notonly the ocular responses, but also those of theextraocular and the neck muscles [20]

\section{Correlations:}

Rothere was no previous studies that correlate the degree of myope by the cervical angles nor range of motion even that [21]. Detected there isIncreases in Electromyography (EMG) amplitudes were observed in the right frontalis, masseter, deltoid, middle trapezius, levator and upper trapezius and upper neck muscles, includingthe splenius. A correlation between visual discomfort and pain in the neck and shoulder has been reported [22] Demonstrated that the functional relation ships between the extra ocular muscle of the myopic and the neck muscle were studied by means of electromyography, with the aim of demonstrating apossible alteration of the posture of the head due to abnormal tonus of the trapezius and sternocleidomastoie muscles in subjects with defective vision which detected marked difference in tonic activity of the named muscles between myopic and normal groups.

In summary, the results of the present study proved that MYOPIA has an adversly effect on cervical spine curve and range of motion. 


\section{Conclusion:}

Within the limitation of this study, the following conclusion are warranted: Myopia has a significant effect on $\mathrm{C}_{1}-\mathrm{C}_{2}$ and $\mathrm{C}_{2}-\mathrm{C}_{7}$ angles and on flexion, extension, right and left rotation cervical R.O.M. and no significant change in $\mathrm{OC}-\mathrm{C} 2$ angle and on right and left bending.

\section{References}

1- ZETTERLAND C., LUNDQVIST L. and RICHTER H.O.: "The Relationship between low vision and Musculoskeletal Complaint". JOPT, Optometry Volume 2, (3): 127-33, 2009.

2- GRBEVSKI S.: "Neck problems, Posture and Refractive Conditions". Mosby St. Louis, London. Journal of Bodywork and Movement Therapies, 39: 1-2, 2009.

3- COHEN S.P.: Epidemiology, Diagnosis, and Treatment of Neck Pain. Mayo Foundation for Medical Education and Research Mayo Clin. Proc., 90 (2): 284-99, 2015.

4- ANAND V., BUCKLEY J.G., SCALLY A. and ELLIOTT D.B.: "Postural stability changes in the elderly with cataract simulation and refractive blur". Invest. Ophthalmol. Vis. Sci., 44 (11): 4670-5, 2003.

5- RICHTER H.O.: "Eye-Neck/scapular area interactions during strenuous near work". Biological plausible pathways with relevance for work related musculoskeletal disorders of the neck and upper extremity. Z. Arb. Wiss., 62: 190-9, 2008.

6- SHADMEH R., SMITH M.A. and KRAKAUER J.W.: "Error correction, Sensory Prediction, and Adaptation in motor control". Motor learning by field approximation, (15): 114-24, 2010

7- HARRISON D.E., HARRISON D.D., HAAS J.W., JANIK T.J. and HOLLAND B.: "Do Sagittal Plane Anatomical Variations (Angulations) of the Cervical Facets and C2 Odontoid Affect the Geometrical Configuration of the cervical Lordosis?" Clin. Anat., (18): 104-11, 2005.

8- SHEREKAR K., YADAV Y.R., BASOOR A.S., BAGHEL A. and ADAM N.: "Clinical implications of alignment of upper and lower cervical spine". Neurology India, 54 (3): 264-7, 2006.

9- HAZEL M. and CLARKSON: "Muscloskeletal assessment. Joint range of motion and manual muscle strength: 2nd edition, Chapter 2, Philidelphia: Lippincott Williams and Wilkins, pp. 38-42, 2000.

10- CLARKSON H.M.: "Joint motion and function assessment, a research based practical guide". Chapter1, Philadelphia: Lippincott Williams and Wilkins, pp. 19-21, 2005.
11- HAZEL M., CLARKSON: "Joint motion and function assessment, a research based practical guide". Chapter1, Philadelphia: Lippincott Williams and Wilkins, pp. 1921, 2005.

12- WEI W., LIAO S., FEI J., WANG Y. and CHEN C.: "Straightened cervical lordosis causes stress concentration: A finite element model study". Australas Phys. Eng. Sci. Med., 36 (1): 27-33, 2013.

13- HARRISON D.D., JANIK T.J., HARRISON G.R., TROY ANOVICH S.J., HARRISON D.E. and HARRISON S.O: "ChiropracticBiophysics Technique: A Linear Algebra Approach to Posture in Chiropractic". J. Manipulative Physiol. Therapy, 19 (8): 525-35, 1996a.

14- HODGSON N.: "Super healthy". Wordclay, pp.: 125-30, 2009.

15- RADCLIFF K., RUBIN T., REITMAN C.A., SMITH J., KEPLER C. and HILIBRAND A.: "Normal cervical alignment". Semin. Spine Surg., 23: 159-64, 2011.

16- RADCLIFF K., RUBIN T., REITMAN C.A., SMITH J., KEPLER C. and HILIBRAND A.: "Normal cervical alignment". Semin. Spine Surg., 23: 159-64, 2011.

17-WANG S., PASSIAS P.G., CUI L., LI G., YAN M., ZHOU H., et al: "Does atlantoaxial dislocation influence the subaxial cervical spine?" Eur. Spine J., 22: 1603-7, 2013.

18- OHARA A., MIYAMOTO K., NAAGANAWA T., MATSUMOTO K. and SHIMIZU K.: "Reliabilities of and correlations among five standard methods of assessing the sagital alignment of the cervical spine". Spine, 31 (22): 2585-91, 2006.

19- MON-WILLIAMS M. and BINGHAM G.P.: "Calibrating reach distance to visual targets". J. Exp. Psychol. Hum. Percept. Perform., 33: 645-56, 2007.

20- RICHTER H.O. : "Eye-Neck/scapular area interactions during strenuous near work". Biological plausible pathways with relevance for work related musculoskeletal disorders of the neck and upper extremity. Z. Arb. Wiss., 62: 190-9, 2008.

21- RICHTER H.O. : "Eye-Neck/scapular area interactions during strenuous near work". Biological plausible pathways with relevance for work related musculoskeletal disorders of the neck and upper extremity. Z. Arb. Wiss., 62: 190-9, 2008.

22- VALENTINO B. and FABOZZO A.: "interaction between the muscles of the neck and the extra ocular muscles of myopic eye, Sug. Radial. Anatomy, 15 (4): 321-3, 1993. 


\section{العلاقة بين الآخطاء البصرية وزوايا الفقرات العثقية ومدى حركتها}

الخلفية: قصر النظر هو واحد من الآخطاء البصرية الإنكسارية الشائعة التى تنتج شكوى العضلات، مثل الصلابة، والتعب والآلم العضلى العيلى فى الرقبة والتى قد تؤثر بدوها على إنحناء العنق ونطاق الصركة. الغرض: التحقيق فى العلاقة بين الآخطاء البصرية المريض وزوايا العنق ونطاق الحركة لآطباء القصر العينى-جامعة القاهرة.

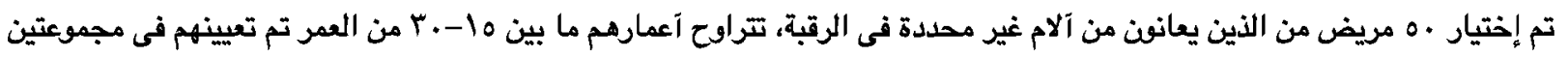

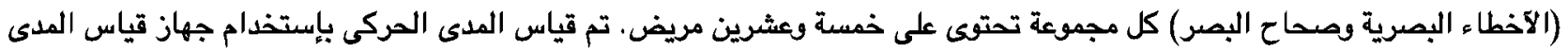
الصركى برنامج الكويلدرورالآشعة السينية.

النتائج: آظهرت المقارنة بين الجموعات عدم وجود إختلاف كبير فى OC-C وإختلاف معنوى في

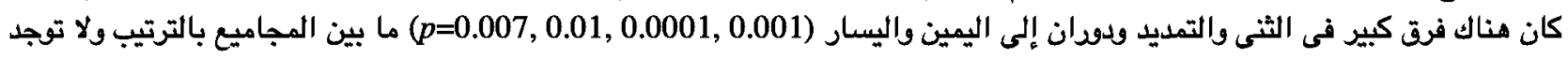

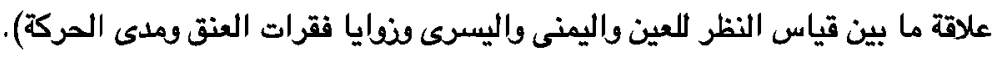

الخلاصة: ضمن حدود هذه الدراسة، هناك ما ييرد الإستنتاجات التالية: قصر النظر له تألآثير كبير على الزوايا

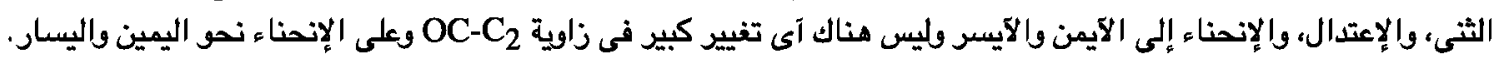

